\title{
Modelling of lysine requirement in broiler breeder hens based on daily nitrogen retention and efficiency of dietary lysine utilization
}

\author{
Juliano Cesar De Paula Dorigam ${ }^{\mathrm{a}}$, Nilva Kazue Sakomura ${ }^{\mathrm{a}, *}$, Letícia Soares ${ }^{\mathrm{a}}$, \\ João Batista Kochenborger Fernandes ${ }^{\mathrm{b}}$, Angela Sünder ${ }^{\mathrm{c}}$, Frank Liebert ${ }^{\mathrm{c}}$ \\ a Department of Animal Science, Universidade estadual paulista "julio de mesquita filho," FCAV/UNESP, Jaboticabal, São Paulo, \\ 14884-900, Brazil \\ b Aquaculture center, Universidade estadual paulista “julio de mesquita filho," FCAV/UNESP, Jaboticabal, São Paulo, 14884-900, Brazil \\ c Division Animal Nutrition Physiology, Georg-August-University, Goettingen, Kellnerweg 6, 37077, Germany
}

\section{A R T I C L E I N F O}

\section{Article history:}

Received 11 April 2016

Received in revised form 4 December 2016

Accepted 11 December 2016

\section{Keywords:}

Dilution technique

Exponential model

Likelihood test

Lysine requirement

Broiler breeder hens

\begin{abstract}
A B S T R A C T
The current feeding programs used for broiler breeder hens need information on how to make use of the genetic potential more efficiently by modelling the amino acid (AA) requirements. Thus, this study aimed to determine the model parameters for maximum nitrogen retention $\left(\mathrm{NR}_{\max } \mathrm{T}\right)$, nitrogen maintenance requirement $(\mathrm{NMR})$ and the efficiency of lysine utilization $\left(\mathrm{bc}^{-1}\right)$ to determine the lysine (Lys) requirements of broiler breeder hens. Nitrogen balance trials were performed in two periods (I: 31-35 wks and II: 46-50 wks). Seven dietary treatments were used with eight replicates and one hen per cage; the treatments consisted of seven diets with protein levels ranging from 58.8 to $311.9 \mathrm{~g} / \mathrm{kg}$ of feed, with Lys being limiting in the dietary protein $(c=3.91 \mathrm{~g}$ of Lys in $100 \mathrm{~g}$ of $\mathrm{CP})$. For each period, nitrogen intake (NI), nitrogen excretion (NEX), nitrogen in egg mass (NEM), nitrogen deposition (ND) and nitrogen retention (NR, NR = ND + NEM + NMR) were obtained in a N balance trial of 25 days. The NMR was calculated as the intersection point of the exponential curve between NEX and $\mathrm{NI}$ at $\mathrm{NI}=0$. The $\mathrm{NR}_{\max } \mathrm{T}$ and $\mathrm{b}$ (slope related to protein quality) were estimated by the exponential fit between NR and NI. The Lys efficiency bc ${ }^{-1}$ was obtained dividing b by c. The likelihood ratio test for the model parameters yielded $255 \mathrm{mg} / \mathrm{BW}_{\mathrm{kg}}{ }^{0.67}$ for NMR, 0.000117 for b and $1684 \mathrm{mg} / \mathrm{BW}_{\mathrm{kg}}{ }^{0.67}$ (period I) and $1484 \mathrm{mg} / \mathrm{BW}_{\mathrm{kg}}{ }^{0.67}$ (period II) for $\mathrm{NR}_{\max } \mathrm{T}$. The necessary Lys intake dependent on NR and Lys efficiency was derived by the equation Lys $=\left(\operatorname{lnNR} R_{\max } T-\ln \left(N_{R_{\max }} \mathrm{T}-\mathrm{NR}\right)\right) /\left(16 \times \mathrm{bc}^{-1}\right)$. Lys intakes required to achieve 0.80 times the maximum potential $\left(\mathrm{NR}_{\max } \mathrm{T}\right)$ were $915 \mathrm{mg}$ and $876 \mathrm{mg}$ in the period $\mathrm{I}$ and II, respectively. For broiler breeder hens, assuming 0.80 times the $\mathrm{NR}_{\max } \mathrm{T}$ value and average efficiency of Lys utilization, $6.02 \mathrm{~g} / \mathrm{kg}$ (31-35 wk) and $5.96 \mathrm{~g} / \mathrm{kg}(46-50 \mathrm{wk}$ ) digestible dietary Lys were observed as optimal digestible Lys concentration in the diet (corresponding to 152 and $147 \mathrm{~g}$ of daily feed intake, respectively). Results of model calculations need verification in performance trials with evaluation of nitrogen deposition and varying dietary Lys efficiencies.
\end{abstract}

(c) 2016 Elsevier B.V. All rights reserved.

\footnotetext{
* Corresponding author.

E-mail addresses: jdorigam@gmail.com (J.C. De Paula Dorigam), sakomura@fcav.unesp.br (N.K. Sakomura), leticia.fcav@gmail.com (L. Soares), jbatista@caunesp.unesp.br (J.B.K. Fernandes), Suender@agr.uni-goettingen.de (A. Sünder), flieber@gwdg.de (F. Liebert).
} 


\section{Introduction}

Over the past years, breeder companies made significant progress in producing more efficient broiler breeder hens with higher egg production. On the other hand, to maintain optimum production of hatching eggs, broiler breeder are fed restrictively to prevent overweight related to reproductive problems (Richards et al., 2010). Therefore, the amino acid (AA) recommendations for broiler breeder hens should be made considering these conditions.

The description of the potential performance of the animal as determined by the genotype is the first step in the determination of amino acid requirements (Hauschild et al., 2015). The modelling procedure as proposed by "Goettingen approach" (Samadi and Liebert, 2007; Samadi and Liebert, 2008; Pastor et al., 2013; Dorigam et al., 2014; Khan et al., 2015; Liebert, 2015) makes use of the maximum "theoretical" nitrogen retention $\left(\mathrm{NR}_{\max } \mathrm{T}\right)$ to characterize the genetic potential, i.e. the asymptote estimated from the exponential function for nitrogen retention (NR) depending on nitrogen intake (NI). The attribute "theoretical" suggests that the $\mathrm{NR}_{\max } \mathrm{T}$ value are generally not in the range of practical performance data but estimate the genetic potential (Samadi and Liebert, 2006). In a previous review, Liebert (2015) stated that the genetic potential is defined as an unreachable "theoretical" threshold value and the potential defined in this way cannot realized even with optimized feeding strategy or environmental conditions. However, the same author mentioned that once the ranking of such threshold value is well defined, no problem exist for further model application. In broiler breeder hens, this concept becomes useful since these birds are not allowed to attain their full genetic potential for growth due to feed restriction regimen but they are fed protein and other nutrients to maximize the potential for egg production and the number of fertile eggs (Richards et al., 2010).

The $\mathrm{NR}_{\max } \mathrm{T}$ parameter is important because current feeding programs need information how to make use of the genetic potential for NR more efficiently and AA requirements therefore. However, experimental data from similar studies are available from Halle et al. (1984b), but insufficiently related to modern broiler breeder hens' genotype. In Halle et al. (1984b) study's, the $\mathrm{NR}_{\max } \mathrm{T}$ value of $1440 \mathrm{mg} / \mathrm{BWkg}^{0.67}$ found for broiler breeder hens at peak production (29-30wks) consider only the NR in the body which is calculated by subtracting the nitrogen deposited in egg mass (NEM) from nitrogen balance data. Recently, this concept has changed and the current researches based on nitrogen utilization models consider also the NEM as a part of total NR (Sünder et al., 2010). This clear have an impact in genetic potential which justify another study to reevaluate the $\mathrm{NR}_{\max } \mathrm{T}$ parameter for modelling purposes.

In poultry nutrition, lysine (Lys) is the second limiting amino acid in practical diets and is mostly used as reference AA to relate other essential AA by the ideal protein concept (Lemme, 2003). A deficiency of Lys results in lower egg production (Domingues et al., 2012). Consequently, the Lys requirement should be known at high level of validity. From a biological point of view, Silva et al. (2015) recommended a daily lysine intake of $643 \mathrm{mg} / \mathrm{hen}$ per day, which is lower than the recommendation of $954 \mathrm{mg} /$ hen per day based on the optimum economic intake of lysine for a population of broiler breeder hens estimated by the Reading model. In another recent study, Ekmay et al. (2013b) found the Lys intake of 909 and $926 \mathrm{mg} /$ hen for product output (egg mass plus body weight gain) and feed conversion, respectively, considering 95\% of the asymptote from the polynomial regression. Although there is different approaches and response criterions, none of them considered NR as criterion to estimate AA requirements. Consequently, it can be summarized that experimental data to derive AA requirements from nitrogen balance data for breeding hens are scarce. Therefore according to mentioned points, the aim of this study was assessing the digestible Lys requirement of broiler breeder hens based on model application (Goettingen approach) taking into account the potential for NR and the dietary Lys efficiency.

\section{Material and methods}

\subsection{Ethics approval}

This study was approved by the Ethics Committee on Animal Use of the Faculty of Agriculture and Veterinary Sciences, UNESP, Jaboticabal (no 9999/14).

\subsection{Birds, housing and experimental design}

Two nitrogen balance trials were conducted at the Laboratory of Poultry Sciences of the University of Agrarian and Veterinary Sciences - FCAV/UNESP, Jaboticabal, São Paulo, Brazil. The N balance trials were performed from 31 to 35 weeks (Period I) and from 46 to 50 weeks of age (Period II). Each study utilized 56 broiler breeder hens of the Ross 308 AP genotype. The hens were individually allotted in a completely randomized design with seven dietary treatments and eight replicates per treatment. The experimental units contained metabolic cages with wire floors, individual feeders and self-drinking systems, respectively. The facilities were equipped with a negative-pressure ventilation system with controlled humidity and temperature, which was kept at $21^{\circ} \mathrm{C}$. The lightning program used was $13 \mathrm{~h}$ of light according to Ross parent stock manual (Aviagen, 2013). 
Table 1

Composition of the experimental diets.

\begin{tabular}{|c|c|c|}
\hline \multirow[t]{2}{*}{ Ingredients (g/kg) } & \multicolumn{2}{|l|}{ Diets } \\
\hline & Summit (N6) & Dilution (N0) \\
\hline Corn & 367.28 & - \\
\hline Soybean meal ( $450 \mathrm{~g} / \mathrm{kg})$ & 351.82 & - \\
\hline Corn gluten meal (600 g/kg) & 180.00 & - \\
\hline Limestone & 68.48 & 63.00 \\
\hline Dicalcium phosphate & 12.96 & 18.90 \\
\hline Soybean oil & 9.57 & 65.00 \\
\hline Salt & 4.63 & 3.30 \\
\hline DL-Methionine $(990 \mathrm{~g} / \mathrm{kg})$ & 2.86 & - \\
\hline Mineral and vitaminic supplement ${ }^{\mathrm{a}}$ & 2.00 & 2.00 \\
\hline L-Tryptophan $(980 \mathrm{~g} / \mathrm{kg})$ & 0.27 & - \\
\hline L-Lysine $\cdot \mathrm{HCl}(780 \mathrm{~g} / \mathrm{kg})$ & 0.10 & - \\
\hline L-Threonine (990 g/kg) & 0.03 & - \\
\hline Potassium chloride & - & 11.40 \\
\hline Corn starch & - & 570.00 \\
\hline Inert (sand) & - & 60.00 \\
\hline Rice husk & - & 178.00 \\
\hline Sugar & - & 28.40 \\
\hline
\end{tabular}

a Content $/ \mathrm{kg}$ - vit. A=9000000 IU, vit. D3=2600000 IU, vit. E=14000 mg, vit. B1=2200 mg, vit. B2=6000 mg, vit. B6=3000 mg, vit. B12=10000 mg, Niacin $=30000 \mathrm{mg}$, pantothenic acid $=15000 \mathrm{mg}$, vit. $\mathrm{K}=1600 \mathrm{mg}$, folic acid $=600 \mathrm{mg}$, selenium $=200 \mathrm{mg}$, manganese $=70000 \mathrm{mg}$, iron $=50000 \mathrm{mg}$, zinc $=50000 \mathrm{mg}$, copper $=8000 \mathrm{mg}$, iodine $=1200 \mathrm{mg}$.

Table 2

Nutritional composition and digestible amino acid content of the diets (as-fed basis).

\begin{tabular}{|c|c|c|c|c|c|c|c|}
\hline \multirow[t]{2}{*}{ Nutrients, g/kg } & \multicolumn{7}{|l|}{ Diets } \\
\hline & N1 & N2 & N3 & $\mathrm{N} 4$ & N5 & N6 & N7 \\
\hline Crude protein & 58.75 & 111.25 & 176.25 & 219.37 & 287.50 & 311.87 & 80.75 \\
\hline Ether extract & 62.40 & 56.84 & 51.29 & 45.73 & 40.18 & 34.62 & 59.36 \\
\hline Crude fiber $^{\mathrm{a}}$ & 64.31 & 56.93 & 49.55 & 42.18 & 34.80 & 27.42 & 60.29 \\
\hline Calcium $^{\mathrm{a}}$ & 30.00 & 30.00 & 30.00 & 30.00 & 30.00 & 30.00 & 30.00 \\
\hline Sodium $^{\mathrm{a}}$ & 1.57 & 1.66 & 1.74 & 1.83 & 1.91 & 2.00 & 1.62 \\
\hline Potassium $^{\mathrm{a}}$ & 6.25 & 6.55 & 6.84 & 7.14 & 7.44 & 7.74 & 6.35 \\
\hline Available Phosphorus ${ }^{a}$ & 3.50 & 3.50 & 3.50 & 3.50 & 3.50 & 3.50 & 3.50 \\
\hline $\operatorname{AMEn}(\mathrm{MJ} / \mathrm{kg})^{\mathrm{b}}$ & 11.70 & 11.70 & 11.70 & 11.70 & 11.70 & 11.70 & 11.70 \\
\hline \multicolumn{8}{|l|}{ Amino acid composition $^{c}$} \\
\hline Lysine & 2.30 & 4.35 & 6.90 & 8.57 & 11.25 & 12.18 & 4.41 \\
\hline Arginine & 2.84 & 5.34 & 8.37 & 10.57 & 13.88 & 15.43 & 2.94 \\
\hline Histidine & 1.37 & 2.54 & 3.98 & 5.15 & 6.58 & 7.29 & 1.49 \\
\hline Isoleucine & 2.20 & 4.23 & 6.58 & 8.15 & 10.74 & 11.58 & 2.55 \\
\hline Leucine & 6.17 & 11.73 & 18.65 & 23.25 & 30.16 & 32.74 & 7.24 \\
\hline Methionine + Cystine & 2.36 & 4.42 & 7.07 & 8.65 & 11.45 & 12.38 & 2.69 \\
\hline Methionine & 1.49 & 2.84 & 4.54 & 5.57 & 7.42 & 7.97 & 1.60 \\
\hline Threonine & 2.24 & 4.24 & 6.69 & 8.27 & 10.88 & 11.80 & 2.51 \\
\hline Phenylalanine & 3.08 & 5.73 & 9.09 & 11.32 & 14.29 & 16.07 & 3.60 \\
\hline Phenylalanine + Tyrosine & 4.99 & 9.43 & 14.91 & 18.60 & 24.37 & 26.50 & 5.72 \\
\hline Tryptophan & 0.52 & 0.99 & 1.56 & 1.96 & 2.55 & 2.80 & 0.60 \\
\hline Valine & 2.58 & 4.88 & 7.73 & 9.61 & 12.65 & 13.63 & 3.14 \\
\hline
\end{tabular}

a Calculated composition using data from the Brazilian Tables for Poultry and Swine (Rostagno et al., 2011).

b Apparent metabolizable energy corrected by nitrogen balance, calculated.

c Analyzed composition of the amino acids in the experimental diets.

\subsection{Experimental diets}

Principles of the diet dilution technique were applied as described by Fisher and Morris (1970). Initially, a Lys limiting summit diet (N6) was formulated to contain $12.18 \mathrm{gLys} / \mathrm{kg}$ feed. Main ingredients were corn and soybean meal. The Lys level in diet N6 provided approximately 1.9 times of the Lys recommendation for Ross parent stock nutrition (Aviagen, 2013). The content of other AAs was adjusted to provide 2.1 times of the expected requirement level to ensure that Lys supply was the limiting factor in each of the diets. According to diet dilution technique, a dilution diet (NO) was formulated to meet the nutritional requirements, except for protein and AAs. The ingredient composition of diets is presented in Table 1.

Graded mixing proportions of the diet N6 and diet N0 yielded the final diets with Lys supply between $2.30 \mathrm{~g} / \mathrm{kg}$ (N1) and $12.18 \mathrm{~g} / \mathrm{kg}$ (N6). Diet N7 aimed to confirm the limiting position of Lys in the experimental diets by supplementation of $2.62 \mathrm{~g}$ L-Lysine $\mathrm{HCl}$ per $\mathrm{kg}$ diet. The nutrient composition of experimental diets is presented in Table 2. 


\subsection{Management and data collection}

Body weight of hens was monitored weekly and egg production was monitored daily until the breeder hens reached the peak of egg production. The first $\mathrm{N}$ balance trial started at 31 weeks of age to obtain data for the peak of egg production. The second $\mathrm{N}$ balance trial started after 15 weeks ( 46 weeks of age) when a decline of egg production was observed. The selection and distribution of the broiler breeder hens in each experimental unit were performed according to body weight and egg production, based on recommendations of Sakomura and Rostagno (2016). To control the differences in body weight, the hens were weighed individually and the heavier and lighter hens were discarded considering the maximum coefficient of variation (CV) of $10 \%$ of the average body weight. The mean body weight of the selected hens at the beginning of the trials was $3.935 \mathrm{~kg}$ with a CV of $8.894 \%$ at $31 \mathrm{wks}$ and $4.004 \mathrm{~kg}$ with a CV of $9.641 \%$ at $46 \mathrm{wks}$. After eliminating the effect of body weight, the distribution of the hens in the experimental units were made according to the egg production, so that the average egg production in the experimental units were similar. To control the differences in the egg production and to confirm that all hens are laying eggs regularly, it was performed an individual control of the egg production during 14 days before starting the trial. Thus, the mean egg production of the selected hens at the beginning of the trials were $86.84 \%$ with a CV of $2.51 \%$ and at $31 \mathrm{wks}$ and $67.10 \%$ with a CV of $3.07 \%$ at $46 \mathrm{wks}$.

In each age period, $\mathrm{N}$ balance trials were divided into five days of adaptation period to the experimental diets and 20 days of quantitative collection both of excreta and eggs. The collection period of 20 days was adopted because the egg production in a hen is determined by the length of her oviposition sequences and by the number and duration of the pauses (when there is no egg production) and broiler breeders have a much poorer rate of laying (more pause days) than commercial laying hens (Nonis, 2007). In certain occasions, hens with pause intervals greater than one day duration can result in the rate of egg production falling below 50\%, consequently, the efficiency in which dietary nitrogen is utilized declines because yolk protein synthesis becomes phasic and fewer follicles are developed (Fisher, 2013). In our understanding, the NEM value is an important part of total $\mathrm{N}$ retention that should be considered in further estimation of the genetic potential as well as the utilization efficiency of dietary protein and amino acids for broiler breeder hens and commercial laying hens. Thus, the procedure used here for selecting birds based on egg production during 14 days of observation prior to the beginning of the trial helps to minimize the influence of the irregularity of egg production in $\mathrm{N}$ balance data, since the hens with higher number of pauses were discarded.

The daily feed supply was $152 \mathrm{~g}$ from 31 to 35 weeks and slightly decreased to $147 \mathrm{~g}$ from 46 to 50 weeks, according to recommendations for hens kept in cages (Van Daele, 2014). The excreta were collected twice a day in trays, stored in plastic pots and weighed at the end of each collection period. The hens were weighed at the start and at the end of the experiment to measure body weight. The leftovers were weighed daily to measure real feed intake. The egg production and egg mass were measured daily to calculate egg mass production.

\subsection{Chemical analysis}

The excreta and eggs collected from each experimental unit during each period were homogenised. The total samples were frozen and freeze-dried for $72 \mathrm{~h}$ at $-80^{\circ} \mathrm{C}$ under $800 \mathrm{mbar}$ of pressure (Edwards ${ }^{\circledR} 501$ Modulyo freeze drier, West Sussex, United Kingdom). The samples were weighed to quantify the dry matter content and milled using a Micro Mill $\left(\right.$ IKA ${ }^{\circledR}$ A11 Basic Analytical Mill, Staufen, Germany). The N content of the diets, excreta and eggs was analysed in a N distiller (Kjeltec $^{\mathrm{TM}} 8400$ Foss, Foss, Hillerod, Denmark) using the Kjeldhal method (Method No. 2001.11) according to AOAC (2005). The factor 6.25 was used to convert nitrogen content to crude protein (CP). The total amino acid content of the ingredients and the experimental diets was analysed by high-performance liquid chromatography (HPLC). The digestible AA data were calculated based on the tables of Rostagno et al. (2011).

\subsection{Modelling}

The first step in modeling the amino acid requirements by the "Goettingen approach" is to determine the nitrogen maintenance requirement (NMR), which is a part of the total nitrogen retention (NR) indicating the amount of nitrogen to be deposited to replace endogenous losses via excreta. According to earlier reports (Samadi and Liebert, 2007; Samadi and Liebert, 2008; Pastor et al., 2013; Khan et al., 2015; Liebert, 2015) a regression analysis between nitrogen intake and nitrogen excretion was applied to estimate NMR following the exponential function:

$$
\mathrm{NEX}=\mathrm{NMR} * \exp ^{\mathrm{b} * \mathrm{NI}}
$$

Where NMR is the nitrogen maintenance requirement $\left(\mathrm{mg} / \mathrm{BW}_{\mathrm{kg}}{ }^{0.67}\right.$ per day), NI is the nitrogen intake (mg/BW ${ }_{\mathrm{kg}}{ }^{0.67}$ per day), NEX is the nitrogen excretion ( $\mathrm{mg} / \mathrm{BW}_{\mathrm{kg}}{ }^{0.67}$ per day), $\mathrm{b}$ is the slope of the exponential function and exp is the base number of the natural logarithm $(\ln )$. The NMR was estimated by calculating the intercept of the curve on the $y$-axis (NEX) when $\mathrm{NI}=0$. The exponential model (1) was fitted to nitrogen excretion data by using nonlinear optimization technique (Levenberg-Marquardt) with SAS (Statistical Analysis System, version 9.1).

Once the NMR was estimated it is possible to calculate the nitrogen retention (NR). The egg mass was calculated by multiplying the egg weight by the egg production and then multiplied by the nitrogen content in the egg to calculate the amount of nitrogen deposited in egg mass (NEM). The nitrogen deposition in the body (ND) was calculated as the difference 
between NI and NEX. The nitrogen retention (NR) represents the total nitrogen utilization by the hen, therefore, it was calculated as: NR $=$ ND + NEM + NMR (Sünder et al., 2010).

The next step in the modeling procedure proposed by the "Goettingen approach" is to determine the "theoretical" maximum nitrogen retention $\left(\mathrm{NR}_{\max } \mathrm{T}\right)$ which is represented by the asymptote of the exponential function and is used to ranking the NR performance data. Therefore, a regression analysis between NI and NR was performed to fit another exponential model as presented in several studies with growing animals (Samadi and Liebert, 2007; Samadi and Liebert, 2008; Pastor et al., 2013; Khan et al., 2015; Liebert, 2015):

$$
\mathrm{NR}=\mathrm{NR}_{\max } \mathrm{T} *\left(1-\exp ^{-\mathrm{b} * \mathrm{NI}}\right)
$$

Where $\mathrm{NR}$ is the nitrogen retention $\left(\mathrm{mg} / \mathrm{BW}_{\mathrm{kg}}{ }^{0.67}\right.$ per day), $\mathrm{NR}_{\max } \mathrm{T}$ is the "theoretical" maximum nitrogen retention $\left(\mathrm{mg} / \mathrm{BW}_{\mathrm{kg}}{ }^{0.67}\right.$ per day), $\mathrm{NI}$ is the nitrogen intake $\left(\mathrm{mg} / \mathrm{BW}_{\mathrm{kg}}{ }^{0.67}\right.$ per day), $\mathrm{b}$ is the slope of the NR curve expressing the dietary protein quality and exp is the base number of the natural logarithm (ln). The exponential model (2) was fitted to NR data also by using nonlinear optimization technique (Levenberg-Marquardt) in SAS (Statistical Analysis System, version 9.1). The $\mathrm{NR}_{\max } \mathrm{T}$ is the asymptotic value in the exponential function, which was estimated by a statistical procedure following several iterations steps by the Levenberg-Marquardt algorithm until the sum of the squares of the residual is minimized. Therefore, the attribute "theoretical" is given to this parameter because the value estimated is not attainable under practical condition, even if the hens are bred under perfect conditions. However, this is an important parameter within the modeling procedure to derive AA requirements for defined graded levels to make use of the theoretical maximum within the scope of practical data.

The Lys requirement was calculated after a logarithimic transformation of the equation (2) according to earlier reports (Samadi and Liebert, 2007; Samadi and Liebert, 2008; Pastor et al., 2013; Liebert 2015; Khan et al., 2015; Liebert, 2015):

$$
\mathrm{LAAI}=\left(\ln \mathrm{NR}_{\max } \mathrm{T}-\ln \left(\mathrm{NR}_{\max } \mathrm{T}-\mathrm{NR}\right)\right) /\left(16 * b c^{-1}\right)
$$

Where LAAI is the necessary daily intake of the limiting AA $\left(\mathrm{mg} / \mathrm{BW}_{\mathrm{kg}}{ }^{0.67}\right)$, NR is the nitrogen retention $\left(\mathrm{mg} / \mathrm{BW}_{\mathrm{kg}}{ }^{0.67}\right.$ per day), $\mathrm{NR}_{\max } \mathrm{T}$ is the "theoretical" maximum nitrogen retention $\left(\mathrm{mg} / \mathrm{BW}_{\mathrm{kg}}{ }^{0.67}\right.$ per day), $\mathrm{c}$ is the concentration of the limiting AA in the feed protein $(\mathrm{g} / 16 \mathrm{~g} \mathrm{~N}), \mathrm{b}$ is the slope of the NR curve expressing the dietary protein quality, and $b c^{-1}$ is the efficiency parameter of utilization of the limiting AA in the diet (slope between $b$ and $c$ ). The number 16 results from limiting AA concentration in the dietary protein $(\mathrm{g} / 16 \mathrm{~g} \mathrm{~N})$. Lys was adjusted as limiting AA in the experimental diets. Consequently, Lys requirements were derived according to equation (3) and the optimal level of Lys in the diet was calculated as the Lys requirement $(\mathrm{g} / \mathrm{d})$ divided by the feed intake $(\mathrm{g})$ multiplied by 100 . The feed intake used in the simulation was derived from metabolizable energy (ME) requirement according to Ross 308AP parent stock manual. In addition, it was considered the required ME intake for broiler breeder hens raised in floor and considering 0.90 and 0.80 times the ME requirement for hens raised in cages to simulate the feed intake in these three scenarios as mentioned by Van Daele (2014).

\subsection{Statistical analysis}

The $\mathrm{N}$ balance data were statistical analyzed by a one-way ANOVA using a GLM procedure and were fitted to exponential models using PROC NLIN procedure in SAS (Statistical Analysis System, version 9.1).

In previous studies, an average value is usually applied as the 'working value' for NMR since the results within the age periods are similar (Samadi and Liebert, 2008). Thus, to give a properly statistical approach, the objective here is to verify if there are differences among the model parameters (NMR, $\mathrm{NR}_{\max } \mathrm{T}$ and $\mathrm{b}$ ) and to verify the equality of the adjusted exponential models (1) and (2) in each age period using the nitrogen balance data.

The fitted models (1) and (2) for broiler breeder hens in each period were compared using a statistical analysis to verify the similarity of model parameters. The following hypotheses were tested:

(1) $\mathrm{HO}: \mathrm{NMR}_{\text {(periodl) }}$ or $\mathrm{NR}_{\max } \mathrm{T}_{\text {(periodl) }}=\mathrm{NMR}_{\text {(periodII) }}$ or $\mathrm{NR}_{\max } \mathrm{T}_{\text {(periodII) }}=\mathrm{NMR}_{\text {(periodI+II) }}$ or $\mathrm{NR}_{\max } \mathrm{T}_{\text {(periodI+II) }}$ vs. H1: not all NMRs or $\mathrm{NR}_{\max }$ Ts are equal;

(2) H0: $\mathrm{b}_{\text {(periodl) }}=\mathrm{b}_{\text {(periodII) }}=\mathrm{b}_{\text {(periodl+II) }}$ vs. H1: Not all $\mathrm{b}$ are equal;

(3) $\mathrm{HO}: \mathrm{NMR}_{\text {(periodl) }}$ or $\mathrm{NR}_{\max } \mathrm{T}_{\text {(periodl) }}=\mathrm{NMR}_{\text {(periodII) }}$ or $\mathrm{NR}_{\max } \mathrm{T}_{\text {(periodII) }}=\mathrm{NMR}_{\text {(periodl+II) }}$ or $\mathrm{NR}_{\max } \mathrm{T}_{(\text {periodl+II) }}$ and $\mathrm{b}_{(\text {periodl) }}=\mathrm{b}_{(\text {periodII) }}=\mathrm{b}_{\text {(periodI+II) }}$ vs. H1: at least one parameter is not equal (NMR, NR $\max \mathrm{T}$ or $\mathrm{b}$ );

Based on these hypotheses, the following models were adjusted: $\Omega=$ unrestricted model, where the two parameters (NMR or $\mathrm{NR}_{\max } \mathrm{T}$ and $\mathrm{b}$ ) were adjusted for each period; $\omega_{1}=$ restricted model, where the NMR or $\mathrm{NR}_{\max } \mathrm{T}$ parameter is common for both periods; $\omega_{2}=$ restricted model, where the $\mathrm{b}$ parameter is common for both periods; $\omega_{3}=$ restricted model, with all parameters common for both periods. The likelihood ratio test was used to test these hypotheses according to statistical procedures proposed by Regazzi (2003) and Carvalho et al. (2010).

\section{Results}

The results obtained from the $\mathrm{N}$ balance trials in periods I (31-35 weeks) and II (46-50 weeks) are presented in Table 3.

The observed NR of hens fed the Lys supplemented diet (N7) confirmed that Lys was in fact the limiting AA in the experimental diets. No significant differences were observed in body weight between the treatments for period I and II $(P>0.05)$. The $\mathrm{N}$ content in egg mass produced (per metabolic body weight) did not differ between treatments in periods I 
Table 3

Summarized results of nitrogen balance trials $(\mathrm{n}=8)$ with broiler breeder hens (Ross 308AP) receiving graded levels of protein limiting in lysine (3.91 $\mathrm{g}$ Lys/100 $\mathrm{g}$ protein $)^{\mathrm{a}}$ in age periods I and II used for determination of model parameters.

\begin{tabular}{|c|c|c|c|c|c|c|c|c|c|}
\hline \multicolumn{10}{|l|}{ Period I (31-35 wks) } \\
\hline Variables measured & N1 & $\mathrm{N} 2$ & N3 & N4 & N5 & N6 & $N 7^{b}$ & $\mathrm{RSD}^{\mathrm{c}}$ & p-value \\
\hline Mean body weight (kg) & 3.84 & 3.99 & 4.16 & 4.22 & 4.24 & 4.22 & 3.81 & 0.17 & NS \\
\hline Feed intake (g/d) & 148 & 151 & 150 & 151 & 151 & 150 & 148 & 3.33 & NS \\
\hline Nitrogen intake $\left(\mathrm{mg} / \mathrm{BW}_{\mathrm{kg}}{ }^{0.67}\right)$ & 572 & 1063 & 1633 & 2003 & 2647 & 2854 & 658 & 57.63 & $* * *$ \\
\hline Nitrogen excretion (mg/BW $\left.{ }_{\mathrm{kg}}{ }^{0.67}\right)$ & 305 & 418 & 853 & 1095 & 1742 & 1888 & 273 & 76.24 & $* * *$ \\
\hline Nitrogen deposition $\left(\mathrm{mg} / \mathrm{BW}_{\mathrm{kg}}{ }^{0.67}\right)$ & 267 & 646 & 780 & 908 & 905 & 966 & 384 & 18.71 & $* * *$ \\
\hline \multicolumn{9}{|l|}{ Period II (46-50 wks) } & NS \\
\hline Variables measured & $\mathrm{N} 1$ & $\mathrm{~N} 2$ & N3 & N4 & N5 & N6 & $\mathrm{N}^{2}$ & $\mathrm{RSD}^{3}$ & p-value \\
\hline Mean body weight (kg) & 3.95 & 4.03 & 4.15 & 4.16 & 4.39 & 4.21 & 3.91 & 0.16 & NS \\
\hline Feed intake (g/d) & 144 & 144 & 145 & 146 & 144 & 145 & 144 & 3.39 & NS \\
\hline Nitrogen intake $\left(\mathrm{mg} / \mathrm{BW}_{\mathrm{kg}}{ }^{0.67}\right)$ & 539 & 1007 & 1573 & 1971 & 2467 & 2755 & 619 & 59.60 & $* * *$ \\
\hline Nitrogen excretion $\left(\mathrm{mg} / \mathrm{BW}_{\mathrm{kg}}{ }^{0.67}\right)$ & 344 & 495 & 822 & 1145 & 1497 & 1748 & 351 & 98.67 & $* * *$ \\
\hline Nitrogen deposition $\left(\mathrm{mg} / \mathrm{BW}_{\mathrm{kg}}{ }^{0.67}\right)$ & 195 & 512 & 751 & 826 & 970 & 1007 & 268 & 37.60 & $* * *$ \\
\hline Nitrogen deposition in egg mass $\left(\mathrm{mg} / \mathrm{BW}_{\mathrm{kg}}{ }^{0.67}\right)$ & 189 & 214 & 237 & 277 & 230 & 231 & 192 & 68.43 & NS \\
\hline
\end{tabular}

a $\mathrm{N} 1=2.30 \mathrm{~g}$ lysine $/ \mathrm{kg}(9.40 \mathrm{~g}$ crude protein $/ \mathrm{kg}), \mathrm{N} 2=4.35 \mathrm{~g}$ lysine $/ \mathrm{kg}$ ( $17.80 \mathrm{~g}$ crude protein $/ \mathrm{kg}), \mathrm{N} 3=6.90 \mathrm{~g}$ lysine $/ \mathrm{kg}$ (28.20 g crude protein $/ \mathrm{kg})$, $\mathrm{N} 4=8.57 \mathrm{~g}$ lysine $/ \mathrm{kg}$ (35.10 g crude protein $/ \mathrm{kg}), \mathrm{N} 5=11.25 \mathrm{~g}$ lysine $/ \mathrm{kg}$ ( $46.00 \mathrm{~g}$ crude protein $/ \mathrm{kg}), \mathrm{N} 6=12.18 \mathrm{~g} \mathrm{lysine} / \mathrm{kg}(49.90 \mathrm{~g}$ crude protein $/ \mathrm{kg})$.

b $\mathrm{N} 7$ is the counter-proof treatment $(\mathrm{N} 1+2.62 \mathrm{~g}$ of L-lysine. $\mathrm{HCl}(780 \mathrm{~g} / \mathrm{kg})$ per $\mathrm{kg}$ of feed $)$.

c Residual standard deviation, expressed in the same units as the related variable.

NS, not significant.

p $<0.001$.

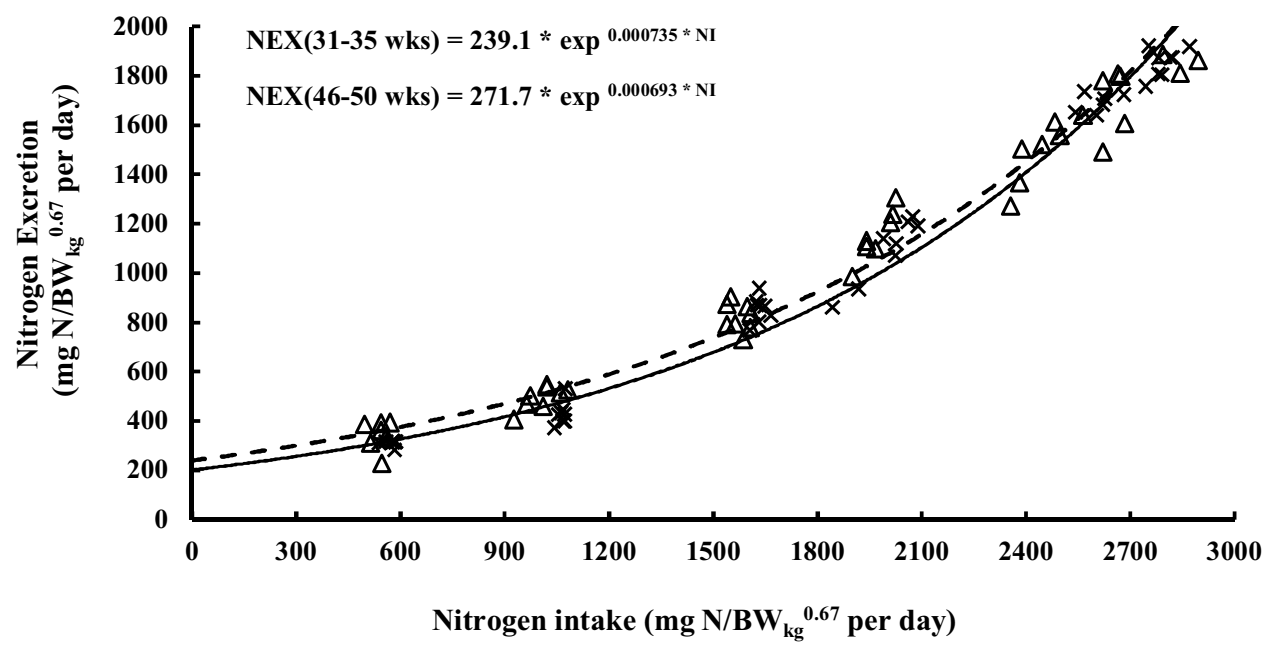

Fig. 1. Estimation of the nitrogen requirements for maintenance by fitting an exponential function between the nitrogen intake (NI) and nitrogen excretion (NEX) during a gradual increase in supplied protein limited in lysine for broiler breeder hens from 31 to $35 \mathrm{wks}$ and from 46 to $50 \mathrm{wks}$. Observed ( $x$ ) and predicted (-) values for period I (31-35wks). Observed $(\Delta)$ and predicted (-----) values for broiler breeder in period II (46-50wks).

and II $(P>0.05)$. The effect of the diets were observed in the NR in periods I and II $(P<0.05)$, which sharply raised from N1 to N4 and then stabilized the response up to N6 diet. Although the NR response stabilized from N5 to N6, the NEX in function of the NI increased exponentially in both periods (Fig. 1).

The NMR values obtained in this study increased from $239.1 \mathrm{mg} / \mathrm{BW}_{\mathrm{kg}}{ }^{0.67}$ per day (Period I) to $271.7 \mathrm{mg} / \mathrm{BW}_{\mathrm{kg}}{ }^{0.67} \mathrm{per}$ day (Period II). The data were submitted to the likelihood ratio test to certify that an average value can be applied for both of the age periods (Table 4).

According to the results of the statistical analysis it is possible to make use of the same exponential equation to describe the NMR in both periods $(P>0.05)$. Consequently, the adopted average NMR value for further calculation is $255 \mathrm{mg} / \mathrm{BW}_{\mathrm{kg}} 0.67$ per day.

The results of the non-linear regression fitting between NI and NR demonstrated that $\mathrm{NR}_{\max } \mathrm{T}$ decreased from $1640 \mathrm{mg} / \mathrm{BW}_{\mathrm{kg}}{ }^{0.67}$ per day (period I) to $1554 \mathrm{mg} / \mathrm{BW}_{\mathrm{kg}}{ }^{0.67}$ per day (period II) but with almost similar b value (Fig. 2).

The model parameters $\mathrm{NR}_{\max } \mathrm{T}$ and $b$, obtained for each period were submitted to the likelihood ratio test to verify the equality of the models (Table 5 ).

According to the results of the statistical analysis it is not possible to use the same exponential equation to describe the NR in both periods $(\mathrm{P}<0.05)$. Although the statistical analysis provided no significant differences in the models when one $\mathrm{NR}_{\max } \mathrm{T}$ value is considered for both periods $(P>0.05)$, this hypothesis was rejected because egg mass production as part of NR indeed decreased with age. Otherwise, the hypothesis of equal b value for both periods was accepted $(P>0.05)$, because the same dietary protein quality was used for both periods. Therefore, the adopted averaged b value is 0.00117 for both 
Table 4

Estimative of the NMR and $b$ parameters of the unrestricted $(\Omega)$ and restricted exponential models $\left(\omega_{1}\right.$ to $\left.\omega_{3}\right)$ from the nitrogen balance data obtained in the period I and period II $(n=94)$.

\begin{tabular}{|c|c|c|c|c|c|c|c|c|c|c|c|c|c|}
\hline \multirow[b]{3}{*}{$\begin{array}{l}\text { Adjusted } \\
\text { models }\end{array}$} & \multicolumn{6}{|c|}{ Exponential model parameters } & \multicolumn{4}{|c|}{ Statistics $^{\mathrm{b}}$} & \multicolumn{3}{|c|}{ Accuracy of the models } \\
\hline & \multicolumn{2}{|c|}{ Period I (31-35wks) } & \multicolumn{2}{|c|}{ Period II (46-50wks) } & \multicolumn{2}{|l|}{ Period I+ II } & \multirow[b]{2}{*}{ RSS } & \multirow[b]{2}{*}{$\chi^{\mathrm{b}}$} & \multirow[b]{2}{*}{ d.f. } & \multirow[b]{2}{*}{$P$} & \multirow[b]{2}{*}{$R b$} & \multirow[b]{2}{*}{$\mathrm{CCC}$} & \multirow[b]{2}{*}{$R P E$} \\
\hline & $\mathrm{NMR}_{(31-35 \mathrm{wks})}$ & $b_{(31-35 w k s)}$ & $\mathrm{NMR}_{(46-50 w k s)}$ & $b_{(46-50 w k s)}$ & $\mathrm{NMR}_{(\text {periodI+II) }}$ & $b_{(\text {periodl+II) }}$ & & & & & & & \\
\hline$\Omega$ & 239.1 & 0.000735 & 271.7 & 0.000693 & & & 7367 & & & & 0.99 & 0.92 & 0.43 \\
\hline$\omega_{1}$ & & 0.000712 & & 0.000719 & 254.1 & & 7566 & 3 & 1 & 0.465 & 0.99 & 0.92 & 0.43 \\
\hline$\omega_{2}$ & 251.1 & & 257.1 & & & 0.000716 & 7482 & 1 & 1 & 0.583 & 0.99 & 0.92 & 0.45 \\
\hline$\omega_{3}$ & & & & & 255.1 & 0.000714 & 7599 & 3 & 2 & 0.287 & 0.99 & 0.92 & 0.45 \\
\hline
\end{tabular}

$\mathrm{NMR}=$ nitrogen maintenance requirement; $b=$ slope of the exponential function; $\mathrm{RSS}=$ residual sum of squares; $\chi 2=\mathrm{Chi}$-square; d.f. = degrees of freedom a Adjusted models: $\Omega=$ unrestricted exponential model, where the two parameters (NMR and $b$ ) were adjusted to periods I and II; $\omega_{1}=$ restricted exponential

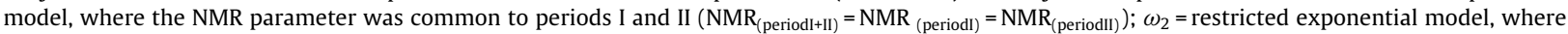

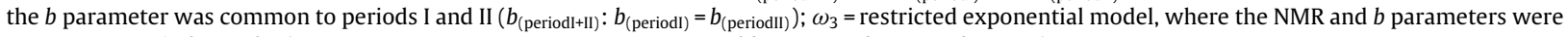
common to periods I and II $\left(\mathrm{NMR}_{(\text {periodI }+\mathrm{II})}=\mathrm{NMR}_{(\text {periodI })}=\mathrm{NMR}_{(\text {periodII })}\right.$ and $\left.b_{(\text {periodI }+\mathrm{II})}=b_{(\text {periodI })}=b_{(\text {periodII })}\right)$.

b Probability of significance $(\alpha=0.05)$.

c $\mathrm{R}^{2}=$ coefficient of determination; $\mathrm{CCC}=$ Concordance correlation coefficient and $\mathrm{RPE}=$ average relative prediction error $(\%)$.

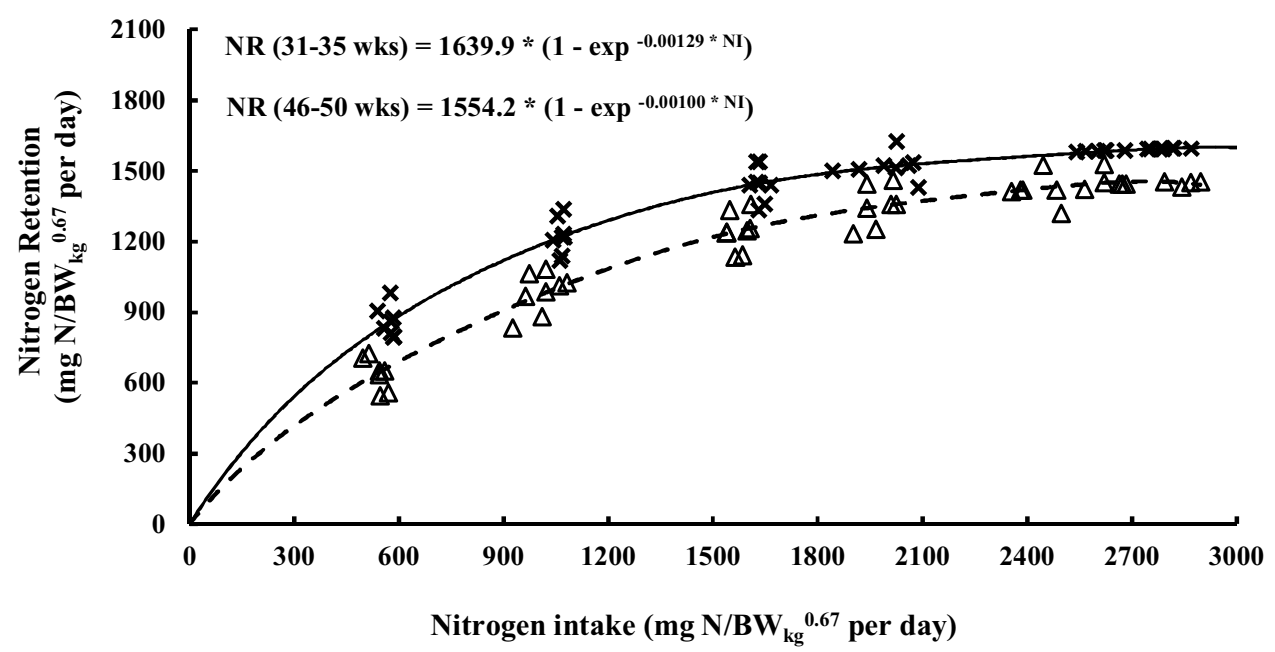

Fig. 2. Estimation of the theoretical potential for nitrogen retention in broilers breeder hens of the Ross 308AP genotype based on the exponential fitting between the daily nitrogen intake (NI) and the daily nitrogen retention (NR) from 31 to 35 wks and from 46 to 50 wks. Observed $(x)$ and predicted $(-)$ values for period I (31-35wks). Observed $(\Delta)$ and predicted (-----) values for broiler breeder in period II (46-50wks).

Table 5

Estimative of the $\mathrm{NR}_{\max } \mathrm{T}$ and $b$ parameters of the unrestricted $(\Omega)$ and restricted exponential models $\left(\omega_{1}\right.$ to $\left.\omega_{3}\right)$ from the nitrogen balance data obtained in the period I and period II $(n=94)$.

\begin{tabular}{|c|c|c|c|c|c|c|c|c|c|c|c|c|c|}
\hline \multirow[b]{3}{*}{$\begin{array}{l}\text { Adjusted } \\
\text { models }^{\mathrm{a}}\end{array}$} & \multicolumn{6}{|c|}{ Exponential model parameters } & \multicolumn{4}{|c|}{ Statistics $^{\mathrm{b}}$} & \multicolumn{3}{|c|}{ Accuracy of the models } \\
\hline & \multicolumn{2}{|c|}{ Period I (31-35wks) } & \multicolumn{2}{|c|}{ Period II (46-50wks) } & \multicolumn{2}{|l|}{ Period I+ II } & \multirow[b]{2}{*}{ RSS } & \multirow[b]{2}{*}{$\chi^{\mathrm{b}}$} & \multirow[b]{2}{*}{ d.f. } & \multirow[b]{2}{*}{$P$} & \multirow[b]{2}{*}{$R b$} & \multirow[b]{2}{*}{ CCC } & \multirow[b]{2}{*}{$R P E$} \\
\hline & $\mathrm{NR}_{\max } \mathrm{T}_{(31-35 \mathrm{ws})}$ & $\overline{b_{(31-35 w k s)}}$ & $\mathrm{NR}_{\max } \mathrm{T}_{(46-50 \mathrm{wks})}$ & $\overline{b_{(46-50 \mathrm{wks})}}$ & $\mathrm{NR}_{\max } \mathrm{T}_{(\text {periodl+II) }}$ & $\overline{b_{\text {(periodl+II) }}}$ & & & & & & & \\
\hline$\Omega$ & 1639.9 & 0.001290 & 1554.2 & 0.001000 & & & 133 & & & & 0.99 & 0.90 & 0.28 \\
\hline$\omega_{1}$ & & 0.001340 & & 0.000908 & 1617.6 & & 392 & 101 & 1 & 0.078 & 0.99 & 0.90 & 0.12 \\
\hline$\omega_{2}$ & 1684.3 & & 1484.0 & & & 0.00116 & 862 & 176 & 1 & 0.059 & 0.99 & 0.90 & 0.43 \\
\hline
\end{tabular}

$\mathrm{NR}_{\max } \mathrm{T}=$ maximum theoretical nitrogen retention; $b=$ slope of the exponential function; RSS = residual sum of squares; $\chi^{2}=$ Chi-square; d.f. $=$ degrees of freedom

aAdjusted models: $\Omega=$ unrestricted exponential model, where the two parameters $\left(\mathrm{NR}_{\max } \mathrm{T}\right.$ and $\left.b\right)$ were adjusted to periods I and II; $\omega_{1}=$ restricted exponential model, where the $\mathrm{NR}_{\max } \mathrm{T}$ parameter was common to periods I and II $\left(\mathrm{NR}_{\max } \mathrm{T}_{\text {(periodl+II) }}=\mathrm{NR}_{\max } \mathrm{T}_{(\text {periodl })}=\mathrm{NR}_{\max } \mathrm{T}_{(\text {periodII) }}\right) ; \omega_{2}=$ restricted exponential model, where the $b$ parameter was common to periods I and II $\left(b_{(\text {periodl+II })}: b_{(\text {periodI })}=b_{(\text {periodII })}\right) ; \omega_{3}=$ restricted exponential model, where the NR $\max T$ and $b$ parameters were common to periods I and II $\left(\mathrm{NR}_{\max } \mathrm{T}_{\text {(periodl+II) }}=\mathrm{NR}_{\max } \mathrm{T}_{\text {(periodl) }}=\mathrm{NR}_{\max } \mathrm{T}_{\text {(periodII) }}\right.$ and $b_{(\text {periodl+II) }}=b_{(\text {periodl) }}=b_{\text {(periodII) }}$ ).

b Probability of significance $(\alpha=0.05)$.

${ }^{c} \mathrm{R}^{2}=$ coefficient of determination; $\mathrm{CCC}=$ Concordance correlation coefficient and $\mathrm{RPE}=$ average relative prediction error (\%). 
Table 6

Model calculation of the lysine requirement (Lys) for broiler breeder hens (Ross 308AP) in age period I (31-35 wks) and II (46-50 wks) depending on the determined efficiency of lysine utilization and different predictions for feed intake.

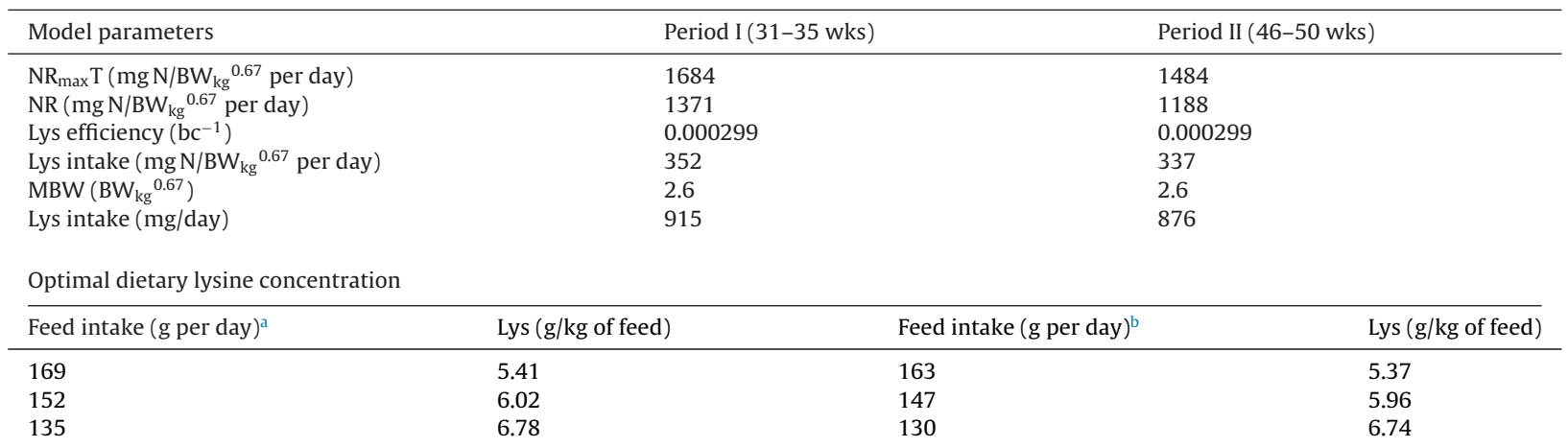

$\mathrm{NR}_{\max } \mathrm{T}=$ maximum theoretical nitrogen retention; $\mathrm{NR}=$ nitrogen retention; $\mathrm{MBW}=$ metabolic body weight.

a The feed intake was calculated based on the recommendation for a daily metabolizable energy (ME) intake of $1.98 \mathrm{MJ} /$ hen per day (31 weeks-old hens) and $11.70 \mathrm{MJ} / \mathrm{kg}$ of feed, simulating three conditions: floor ( $1.98 \mathrm{MJ} /$ hen), cage ( 0.90 times the ME) and cage (0.80 times the ME).

b The Feed intake was calculated based on the recommendation for a daily metabolizable energy (ME) intake of $1.91 \mathrm{MJ} /$ hen per day (46 weeks-old hens) and $11.70 \mathrm{MJ} / \mathrm{kg}$ of feed, simulating three conditions: floor ( $1.98 \mathrm{MJ} /$ hen), cage ( 0.90 times the ME) and cage (0.80 times the ME).

periods and the $\mathrm{NR}_{\max } \mathrm{T}$ values for period I and II are 1684 and $1484 \mathrm{mg} / \mathrm{BW}_{\mathrm{kg}}{ }^{0.67}$ per day, respectively. Accordingly, the parameter for Lys efficiency $\left(b c^{-1}\right)$ for period I and II was calculated as 0.000299 . Based on the derived model parameters and the response of the broiler breeder hens in this study, the daily Lys intake required to achieve 0.80 times the $\mathrm{NR}_{\mathrm{max}} \mathrm{T}$ value were $915 \mathrm{mg}$ and $876 \mathrm{mg}$ in the period I and II, respectively (Table 6).

The optimal dietary Lys concentration between the age periods was equal but may change depending on the real feed intake level.

\section{Discussion}

The objective of this study was to determine the model parameters NMR and $\mathrm{NR}_{\max } \mathrm{T}$ for broiler breeder hens and to apply for further modelling of Lys requirements. The intersection point in the $y$-axis derived from the exponential regression between NEX and NI reflects the inevitable metabolic nitrogen losses (Wecke and Liebert, 2009). Within the model application, the resultant NMR is not used as the real maintenance requirement but is understood to be part of the total nitrogen retention, indicating the requirement to replace the endogenous losses via faeces and urine (Liebert, 2015). The nitrogen losses also includes minimum protein turnover, gut and integument losses (in this case feathers and skin) as stated by Fergusson (2006) which in this current study was not considered separately. On the other hand, the definition of the maintenance requirement may be difficult for broiler breeder hens, because feeding these hens at maintenance does not imply that a constant nitrogen balance is maintained because these hens may deposit protein at the expense of body lipid while they are not producing egg and while they are gaining body weight (Gous, 2012).

The NMR values of 239.1 (31-35wks) and $271.7 \mathrm{mg} / \mathrm{BW}_{\mathrm{kg}}{ }^{0.67}$ per day (46-50wks) are similar to those found in previous studies for males and females broilers of fast-growing genotype within different ages (Samadi and Liebert, 2006, 2007; Dorigam et al., 2014). This similarity between nitrogen endogenous losses in different poultry categories are also observed in Ravindran and Hendriks (2004) study, which found that the endogenous output of nitrogen did not differ between broiler, layer and adult rooster.

The results for NMR show a tendency of increased NMR from 239.1 (31-35wks) to $271.7 \mathrm{mg} / \mathrm{BW}_{\mathrm{kg}}{ }^{0.67}$ per day (46-50wks). Probably this was a reflection of the rate of egg production, because the nitrogen losses from endogenous protein degradation is lower at higher rates of egg production (Ekmay et al., 2013b), which could partially have contributed to the lower NMR in this period. Ekmay et al. (2013a) suggested that there is increased mobilization of body protein mass for egg formation, being most pronounced during early lay and at wk 45, but not at peak production. The main explanation given by those authors is that ubiquitin appears to be the main regulator in protein turnover, which tags a protein for degradation by the proteosome as part of the ubiquitin-proteosome pathway of proteolysis. An increase in the amount of proteins being tagged for degradation could explain how amino acids are liberated for yolk formation and the amino acids of endogenous origin that are not reabsorbed contribute to nitrogen excretion (Adedokun et al., 2011).

From statistical point of view the likelihood test ratio for non-linear models confirmed the equality of both NMR values found in the current study (Table 4). The results indicated that one exponential model can be used to describe the NMR for both periods. Therefore, the value of $255 \mathrm{mg} / \mathrm{BW}_{\mathrm{kg}}{ }^{0.67}$ was adopted as "working value" for the daily NMR of broiler breeders within the age periods under study. The observed averaged NMR ( $\left.255 \mathrm{mg} / \mathrm{BW}_{\mathrm{kg}}{ }^{0.67}\right)$ is close to the NMR value of $259 \mathrm{mg} / \mathrm{BW}_{\mathrm{kg}}{ }^{0.67}$ as reported by Halle et al. (1984a) in the top laying period (29-30wks). A more recent prediction from Rabello et al. (2002) indicates that daily inevitable $\mathrm{N}$ losses would be $248 \mathrm{mg} / \mathrm{BW}_{\mathrm{kg}}{ }^{0.67}$ for broiler breeder hens, which is also close to our results. 
In broiler breeder hens, the protein retention can be affected by the egg production (Ekmay et al., 2013b). Once the hens are not producing eggs $(\mathrm{NEM}=0)$ there is an increase in the amount of body proteins being degraded and amino acids being liberated for yolk formation (Ekmay et al., 2013b), which means a lower body nitrogen deposition and higher nitrogen maintenance requirement due to the increased catabolism of the amino acid that are no being used for protein synthesis. Therefore, the NR decreases since this value represents the sum of ND, NMR and NEM, consequently NR $\max _{T}$ will be lower and a conclusion about the genetic potential cannot be obtained.

The maximum potential for nitrogen retention $\left(\mathrm{NR}_{\max } \mathrm{T}\right)$ is dependent on the nitrogen deposited in egg mass and, since the egg production rate drops within the age of the broiler breeder hens, it is safe to assume that only one $\mathrm{NR}_{\max } \mathrm{T}$ value cannot be described for both age periods and, therefore, the HO (1) hypothesis was discarded. The consequences for using the same $\mathrm{NR}_{\max } \mathrm{T}$ value in both periods is that the calculated Lys requirements would increase within the age, which is not observed in the practice. In this case the threshold value $\left(\mathrm{NR}_{\max } \mathrm{T}\right)$ was $1684 \mathrm{mg} / \mathrm{BW}_{\mathrm{kg}}{ }^{0.67}$ in the peak production (31-35wks) and decreased to $1484 \mathrm{mg} / \mathrm{BW}_{\mathrm{kg}}{ }^{0.67}$ from 46 to $50 \mathrm{wks}$. On the other hand, the b value is dependent on dietary protein quality and independent of the $\mathrm{N}$-intake as demonstrated by Liebert (2015) and, since the same feed was provided for both periods, the hypothesis $\mathrm{HO}(2)$ was adopted and only one b value was used to calculate the efficiency of Lys.

The only experimental data found in the literature about the upper limit for NR of breeder hens (Halle et al., 1984b) yielded $1440 \mathrm{mg} / \mathrm{BW}_{\mathrm{kg}}{ }^{0.67}$ for broiler hens at peak production (29-30wks). This threshold value is $244 \mathrm{mg} / \mathrm{BW}_{\mathrm{kg}}{ }^{0.67}$ lower than the estimate in the current study for peak production. This difference could be due to the genetic improvement of the broiler breeder hens over the past 31 years. If we consider the $\mathrm{NR}_{\max }$ T value of $1440 \mathrm{mg} / \mathrm{BW}_{\mathrm{kg}}{ }^{0.67}$, the $\mathrm{N}$-intake of $2240 \mathrm{mg} / \mathrm{BW}_{\mathrm{kg}}{ }^{0.67}$ and the $b$ value of 0,000526 from Halle et al. (1984b) study, the NR calculated by equation (2) would be $997 \mathrm{mg} / \mathrm{BW}_{\mathrm{kg}}{ }^{0.67}$, which results in the Lys requirement of $348 \mathrm{mg} /$ day using the equation (3) for broiler breeder hen of $1.675 \mathrm{~kg}$ and the bc $\mathrm{bc}^{-1}$ value of 0.000299. This Lys requirement calculated using the information from Halle et al. (1984b) study is extremely low when compared to other estimates from literature. It is possible that this value is low because these authors subtract the nitrogen deposited in egg mass (NEM) from nitrogen balance data resulting in lower $\mathrm{NR}_{\max } \mathrm{T}$ value estimated.

The observed $\mathrm{NR}_{\max } \mathrm{T}$ values are not too far from the NR observed in this study, which was approximately 0.80 times the $N R_{\max } T$ value. However, the $\mathrm{NR}_{\max } \mathrm{T}$ value is utilized only for ranking the $\mathrm{NR}$ data within the procedure of modelling of amino acid requirements (Wecke and Liebert, 2009) because the potential defined in this way (as the asymptotic response of the exponential model) cannot be achieved even with optimized feeding strategy or environmental conditions (Liebert, 2015). The derived optimal Lys intake of $915 \mathrm{mg} /$ day calculated in the current study (Table 6) for broiler breeder hens from 31 to 35 weeks, with a nitrogen retention of $1371 \mathrm{mg} / \mathrm{BW}_{\mathrm{kg}}{ }^{0.67}$ per day that corresponds to 0.81 times the $\mathrm{NR}_{\max } \mathrm{T}$ value $\left(1684 \mathrm{mg} / \mathrm{BW}_{\mathrm{kg}}{ }^{0.67}\right.$ per day) and was generally in line with the data range given in literature. Considering the optimum economic intake of lysine for a population of broiler breeder hens, Silva et al. (2015) estimated $954 \mathrm{mg} / \mathrm{hen}$ per day using the Reading model. For maximum egg mass production, Ekmay et al. (2013b) determined in two consecutive trials the daily requirements of digestible Lys as $909 \mathrm{mg}$ and $919 \mathrm{mg}$ in peak production, respectively. Fakhraei et al. (2010) suggested total daily Lys requirement for 60-wks-old broiler breeders at $1012 \mathrm{mg}$, but assuming 0.87 of Lys digestibility (Ekmay et al., 2013a), the daily requirement would be $881 \mathrm{mg}$ and is closer to the requirements estimated in this study.

An important consideration in this study is that energy maintenance requirement for broiler breeder hens kept in cages can be $0.90-0.80$ times the requirement for hens kept in floor due to the lower activity and lower heat production (Van Daele, 2014) and this can affect the feed intake and, consequently, the recommendation of the dietary Lys concentration. Because of the restricted feeding program of the breeder hens, the energy intake will always be a limiting factor and will affect real feed intake. Therefore, once the amino acid requirement is established, the dietary level will depend on the feed intake as demonstrated (Table 6) when three conditions in which broiler breeders can be reared are simulated. Since the feeding standards for broiler breeders in cages are practically non-existent (Daghir and Jones, 2008), the focus for comparisons will be recommendations for birds reared in floor pens. The dietary Lys concentrations $5.37 \mathrm{~g} / \mathrm{kg}$ Lys calculated in the current study (Table 6) for broiler breeder hens from 46 to 50 weeks, with a nitrogen retention of $1188 \mathrm{mg} / \mathrm{BW}_{\mathrm{kg}} 0.67$ per day that corresponds to 0.80 times the $\mathrm{NR}_{\max } \mathrm{T}$ value $\left(1484 \mathrm{mg} / \mathrm{BW}_{\mathrm{kg}}{ }^{0.67}\right.$ per day) are close to Ross parent stock nutrition specifications (Aviagen, 2013) of $5.60 \mathrm{~g} / \mathrm{kg}$ Lys or breeder hens after 315 days. According to Rostagno et al. (2011), the dietary Lys concentration for a breeder hen with $3 \mathrm{~kg}$ and daily feed intake of $159 \mathrm{~g}$ would be $5.70 \mathrm{~g} / \mathrm{kg} \mathrm{Lys}$, which is also close to our data. These recommendations for the hens reared in cages are slight above those recommendations to compensate the lower feed supply. On the other hand, Van Daele (2014) suggested that there is no need to adjust the AA and protein intake, because this dietary management will help to control body weight gain without affecting egg production under cage conditions.

In conclusion, although the optimal Lys intake and dietary concentrations presented here are similar to those of the literature, it is important to consider that the optimal in-feed recommendations depend on many factors, such as the variation in the daily nitrogen retention and feed intake. In the case of broiler breeder hens, the egg production rate also has directly influence in the nitrogen retention which would affect the requirement for lysine as demonstrated using the values from Halle et al. (1984b) study. Also, the modelling procedure provides an estimate of the maximum genetic potential for nitrogen retention which usually is obtained with ad libitum feeding regimen. Therefore, it is possible to make use of this potential, defined as a percentage of $\mathrm{NR}_{\max } \mathrm{T}$ or deduced daily nitrogen retention as a performance parameter to determine the Lys requirements (Table 6). Compared with our previous study using the Reading model (Silva et al., 2015) to estimate Lys requirements for broiler breeder hens, this procedure is faster, because it is not necessary ten weeks (six of adaptation and four of egg collection) to obtain the results and produce similar results. 
In general, the applied modelling approach provides a number of advantages for improving the methodical base for further calculation of amino acid requirements both for growth and egg production.

\section{Acknowledgements}

The authors gratefully acknowledge Fundação de Amparo a Pesquisa do Estado de São Paulo - FAPESP (Brazil) for financial support (grant number no 2013/07136-5), Ajinomoto Ltd. by the donation of the crystalline amino acids and HPLC analysis, and Aviagen for providing the parent stock.

\section{References}

AOAC, 2005. Official Methods of Analysis, 18th edn. AOAC, Gaithersburg, MD, USA.

Adedokun, S.A., Adeola, O., Parsons, C.M., Lilburn, M.S., Applegate, T.J., 2011. Factors affecting endogenous amino acid flow in chickens and the need for consistency in methodology. Poult. Sci. 90, 1737-1748, http://dx.doi.org/10.3382/ps. 2010-01245.

Aviagen, 2013. Ross Parent Stock Management Handbook. Ross 308. Aviagen Ltd, Midlothian, UK.

Carvalho, L.R., Pinho, S.Z., Mischan, M.M., 2010. Methods to verify parameter equality in nonlinear regression models. Sci. Agric. 67 (2), 218-222, http://dx.doi.org/10.1590/S0103-90162010000200014.

Daghir, N.J., Jones, R., 2008. Breeder and hatchery management in hot climates. In: Daghir, N.J. (Ed.), Poultry Production in Hot Climates. CAB International, Wallingford, pp. 294-330.

Domingues, C.H., Sgavioli, S., Praes, M.F.F.M., Duarte, K.F., Castiblanco, D.M.C., Santos, E.T., Alva, J.C.R., Junqueira, O.M., 2012. Lysine and methionine + cystine for laying hens during the post-molting phase. Rev. Bras. Cienc. Avic. 14 (3), 187-192, http://dx.doi.org/10.1590/S1516-635x2012000300005.

Dorigam, J.C.P., Sakomura, N.K., Hauschild, L., Silva, E.P., Bendezu, H.C.P., Fernandes, J.B.K., 2014. Reevaluation of the digestible lysine requirement for broilers based on genetic potential. Sci. Agric. 71 (3), 195-203, http://dx.doi.org/10.1590/S0103-90162014000300004.

Ekmay, R.D., Salas, C., England, J., Cerrate, S., Coon, C.N., 2013a. The effects of age, energy and protein intake on protein turnover and the expression of proteolysis-related genes in the broiler breeder hen. Comp. Biochem. Physiol. B. Biochem. Mol. Biol. 164 (1), 38-43, http://dx.doi.org/10.1016/j.cbpb.2012.10.002.

Ekmay, R.D., De Beer, M., Mei, S.J., Manangi, M., Coon, C.N., 2013b. Amino acid requirements of broiler breeders at peak production for egg mass, body weight, and fertility. Poult. Sci. 92 (4), 992-1006, http://dx.doi.org/10.3382/ps. 2012-02554.

Fakhraei, J., Loutfollahian, H., Shivazad, M., Chamani, M., Hoseini, S.A., 2010. Reevaluation of lysine requirement based on performance responses in broiler breeder hens. Afr. J. Agric. Res. 5, 2137-2142, http://dx.doi.org/10.5897/AJAR10.161.

Fergusson, N.S., 2006. Basic concepts describing animal growth and feed intake. In: Gous, R.M., Morris, T., Fisher, C. (Eds.), Mechanistic Modelling in Pig and Poultry Production. CAB International, Wallingford UK, pp. 22-53.

Fisher, C., Morris, T.R., 1970. The determination of the methionine requirement of laying pullets by a diet dilution technique. Br. Poult. Sci. 11, 67-82.

Fisher, C., 2013. Protein deposition in poultry. In: Buttery, P.J., Lindsay, D.B. (Eds.), Protein Deposition in Animals: Proceedings of Previous Easter Schools in Agricultural Science. Butterworth-Heinemann Oxford. Rev edn, pp. 251-271.

Gous, R.M., 2012. Simulation Modelling for Predicting Responses in Broiler Breeder and Laying Hens, http://www.facta.org.br/wpc2012-cd/pdfs/plenary/Rob_Gous.pdf (Accessed 05.09.16).

Halle, I., Jeroch, H., Pahle, T., Gebhardt, G., 1984a. On the nitrogen maintenance requirement of the parent broiler laying hen. Arch. Anim. Nutr. 34, 57-64.

Halle, I., Jeroch, H., Gebhardt, G., 1984b. Investigations into the influence of graded N-supplements on egg protein synthesis and protein retention in the bodies of broiler hens. Arch. Anim. Nutr. 34, 615-621.

Hauschild, L., Sakomura, N.K., Silva, E.P., 2015. AvinespModel: predicting poultry growth, energy and amino acid requirements. In: Sakomura, N.K., Gous, R.M., Kyriazakis, I., Hauschild, L. (Eds.), Nutritional Modelling for Pigs and Poultry. CAB International, Wallingford, pp. 188-207, http://dx.doi.org/10.1079/9781780644110.0188.

Khan, D.R., Wecke, C., Sharifi, A.R., Liebert, F., 2015. Evaluating the age-dependent potential for protein deposition in naked neck meat type chicken. Animals 5, 56-70, http://dx.doi.org/10.3390/ani5010056.

Lemme, A., 2003. The ideal protein concept in broiler nutrition. 1. methodological aspects - opportunities and limitations. AminoNews 4, 7-14.

Liebert, F., 2015. Basics and applications of an exponential nitrogen utilization model ('Goettingen approach') for assessing amino acid requirements in growing pigs and meat type chickens based on dietary amino acid efficiency. In: Sakomura, N.K., Gous, R.M., Kyriazakis, I., Hauschild, L. (Eds.), Nutritional Modelling for Pigs and Poultry. CAB International, Wallingford, pp. 73-87, http://dx.doi.org/10.1079/9781780644110.0073.

Nonis, M.K., 2007. Modelling Nutrient Responses and Performance of Broiler Breeders After Sexual Maturity PhD Thesis. University of KwaZulu-Natal, Pietermaritzburg, South Africa.

Pastor, A., Wecke, C., Liebert, F., 2013. Assessing the age-dependent optimal dietary branched-chain amino acid ratio in growing chicken by application of a nonlinear modeling procedure. Poult. Sci. 92, 3184-3195, http://dx.doi.org/10.3382/ps.2013-03340.

Rabello, C.B.V., Sakomura, N.K., Longo, F.A., Resende, K.T., Couto, H.P., 2002. Prediction equation of crude protein requirements for broiler breeder. Rev. Bras. Zootec. 31 (3), 1204-1213.

Ravindran, V., Hendriks, W.H., 2004. Endogenous amino acid flows at the terminal ileum of broilers, layers and adult roosters. Anim. Sci. 79, 265-271.

Regazzi, A.J., 2003. Test for parameter equality in nonlinear regression models. Rev. Ceres 50, 9-26.

Richards, M.P., Rosebrough, R.W., Coon, C.N., Mc Murtry, J.P., 2010. Feed intake regulation for the female broiler breeder: in theory and practice. J. Appl. Poult. Res. 19, 182-193, http://dx.doi.org/10.3382/japr.2010-00167.

Rostagno, H.S., Albino, L.F.T., Donzele, J.L., Gomes, P.C., Oliveira, R.F., Lopes, D.C., Ferreira, A.S., Barreto, S.L.T., Euclides, R.F., 2011. Brazilian Tables for Poultry and Swine: Composition of Feedstuffs and Nutritional Requirements, 3rd edn. UFV publishing, MG, BR.

Sünder, A., Wecke, C., Liebert, F., 2010. Ergebnisse zur Anwendung eines exponentiellen N-Verwertungsmodells bei der Bewertung des Aminosäurebedarfes für Legehennen modernen Genotyps: schätzung des N-Erhaltungsbedarfes und maximalen N-Retentionsvermögens in der Legespitze. In: Gierus, H. (Ed.), 11th Tagung Schweine Und Geflügelernährung. Universität Halle-Wittenberg, pp. 62-64.

Sakomura, N.K., Rostagno, H.S., 2016. Métodos De Pesquisa Em Nutrição De Monogástricos, 2rd edn. FUNEP, SP, BR.

Samadi, Liebert, F., 2006. Estimation of nitrogen maintenance requirement and potential for nitrogen deposition in fast growing chicken depending on age and sex. Poult. Sci. 85, 1421-1429, http://dx.doi.org/10.1093/ps/85.8.1421.

Samadi, Liebert, F., 2007. Lysine requirement of fast growing chickens-effect of age, sex, level of protein deposition and dietary lysine efficiency. J. Poult. Sci. 44, 63-72, http://dx.doi.org/10.1093/ps/86.6.1140.

Samadi, Liebert, F., 2008. Modelling the optimal lysine to threonine ratio in growing chickens depending on age and efficiency of dietary amino acid utilization. Br. Poult. Sci. 49, 45-54, http://dx.doi.org/10.1080/00071660701821667.

Silva, E.P., Sakomura, N.K., Oliveira, C.F.S., Costa, F.G.P., Dorigam, J.C.P., Malheiros, E.B., 2015. The optimal lysine and threonine intake for Cobb broiler breeder hens using reading model. Livest. Sci. 174, 59-65, http://dx.doi.org/10.1016/j.livsci.2015.01.009.

Van Daele, K., 2014. Small Pen Housing Management for Breeder Strains Internal Briefing. Aviagen Ltd, Midlothian, UK.

Wecke, C., Liebert, F., 2009. Lysine requirement studies in modern genotype barrows dependent on age, protein deposition and dietary lysine efficiency. J. Anim. Physiol. Anim. Nutr. 93, 295-304, http://dx.doi.org/10.1111/j.1439-0396.2009.00923.x. 